$$
\text { Linguistik Terapan } 18 \text { (2) (2021): } 101 \text { - } 108
$$

Jurnal Linguistik Terapan Pascasarjana

Available online

http://jurnal.unimed.ac.id/2019/index.php/JLT-Unimed

\title{
FACTORS SLOW SECONDARY LEARNESR DIFFICULTIES IN LEARNING SPEAKING AT HOMESCHOOLING
}

\author{
Devi Lusiana \\ Anni Holila Pulungan \\ Rahmad Husein \\ English Applied Linguistic Program \\ Postgraduate Program-Universitas Negeri Medan
}

Diterima Mei 2021; Disetujui Juni 2021; Dipublikasikan Agustus 2021

\begin{abstract}
This research deals with factors slow secondary learners difficulties in learning speaking at Homeschooling Global Lentera Kasih Batam. This research was conducted by using qualitative research. The objectives of this study was to investigate the factors causing slow secondary learners difficulties in learning speaking English. The data of this study obtained from documentation and interview. The techniques of collecting data that was applied in this research- they are observation, interview and documentation. The data of this study obtained from the result of interview from teacher and parents of slow learners. The source of data in this study was slow secondary learners grade $X$ and the English teacher. There were 2 English teachers, and 2 classes of secondary level learners in Homeschooling Global Lentera Kasih and both slow learners classes contains 4 students, in class X-1 they are FL, NM, RRH and PLG, while in class X-2, they are DA, KT, SRN and FDF. The results showed that there were two factors caused the difficulties of slow learners in learning speaking, they are emotional and personal factors.
\end{abstract}

Keywords: Factors, Slow Learners, Difficuties , Learning, Homeschooling

How to Cite: Lusiana, Devi. (2021). Factors Slow Secondary Learners Difficulties in Learning Speaking at Homeschooling. Jurnal Linguistik Terapan-Pascasarjana Unimed. 18 (2): $101-108$.

ISSN: 2407 - 7410

\section{INTRODUCTION}

Speaking is an ability to convey the information or expressing one's thoughts feelings in spoken language. Speaking ability should be mastered by students to facing global era. Moreover, by mastered speaking English students can communicate with another people in oral communication. Absolutely everyone certain find themselves in situations where they have had to speak publically. Brown (2001) states that speaking as an interactive process of 
constructing meaning, involving producing, receiving and processing information. It means that before someone try to speak, they need to think and build the meaning in their mind first, next they need to process the information then finally utter the sentence perfectly with the well structure.

The aims of teaching speaking are to improve the oral production of the students. As Richards and Renandya (2005) state that since the purpose of language teaching is to provide learners with the communicative competence, classroom activities seem to be an important component of a language course. Therefore, the teacher should consider engaging students become communicative. So, to know how students can speak, the teacher gives some strategy and then engages the students to make them confidence to express their opinion. The teacher must ensure what is taught and know the condition of the students to be taught.

Secondary learners describe as institution that provides secondary education or called as middle education. Some secondary schools provide both lower secondary education (12 to 15 years of age) and upper secondary education (15 to 18 years of age) but these can also be provided in separate schools. In Indonesia, schools typically admit pupils between 11 and 16 years of age.

Slow learner is not a diagnostic category, it is a term people use to describe a student who has the ability to learn necessary academic skills, but at rate and depth below average same age peers. In order to grasp new concepts, a slow learner needs more time, more repetition, and often more resources from teachers to be successful. As Malik (2009) argues that slow learner students usually have a combination of various obstacles in learning. The challenge is to teach these lessons to children with special needs, specifically for children who are slow to learn. With the intellectual under the child in general, it makes the difficulties in understanding of slow learner children. This kind of students need extra supports such as; repetition to help students make a concept more concrete, encourage other activities in which learners can experience success and keep them connected, differentiate instruction, tutoring to help fill in gaps in basic skills and it helps a student stay caught up, teach study skills to help a student become more efficient in studying, teach the most important concepts and leave out some of the less important details, and peer tutoring. Teachers should leave more time for slow learners in classroom talk and provide elicitations when it is necessary. Slow learners usually show delays in thinking, decision, hard to find common ground, intimacy, hard to give reasons, and even bad memories. Some slow learners do not attend formal schools for fear of not being able to participate in learning like other 
students. So some of the slow learners choose special schools and some choose to homeschooling.

Homeschooling refers to home education. The common understanding is homeschooling education model where a family chooses to be solely responsible for their children's education by using home as a base education. Mulyadi (2007) points out homeschooling will teach children with a variety of situations, conditions, and social environment that continues to grow.

\section{METHODOLOGY}

This research was conducted by applying a descriptive research design. Bogdan \& Biklen (1992) proposed the descriptive qualitative design as the researcher's plan of how to proceed, while Potter (1996) states that Naturalistic design is when the research main focus is to observe person or persons in their natural state as undisturbed as possible.

The data of this study obtained from documentation and interview. The techniques of collecting data that was applied in this research- they are observation, interview and documentation. The data of this study obtained from the result of interview from teacher and parents of slow learners. The source of data in this study was slow secondary learners grade $\mathrm{X}$ and the English teacher. There were 2 English teachers, and 2 classes of secondary level learners in Homeschooling Global Lentera Kasih and both slow learners classes contains 4 students, in class X-1 they are FL, NM, RRH and PLG, while in class X-2, they are DA, KT, SRN and FDF.

\section{FINDINGS AND DISCUSSION}

Theoretically Reddy, Ramar and Kusuma (2006) proposed factors of Slow learner are poverty, parental intelligence and number of family members, emotional factors, and personal factors are the four factors that cause slow learners.

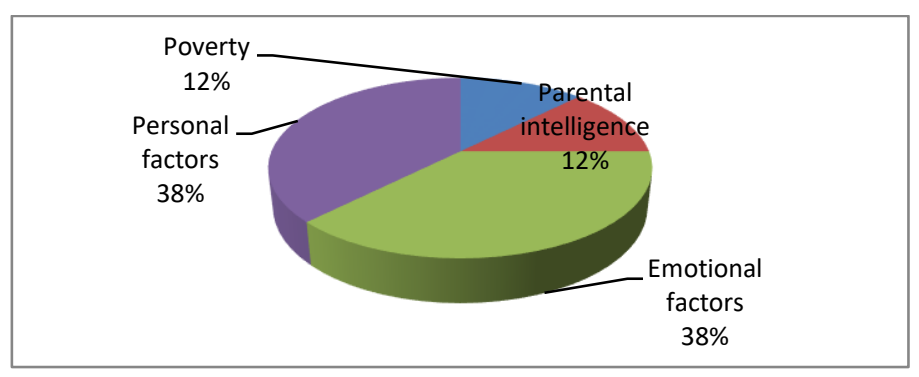

Chart 1. the Proportions Factors Cause Difficulties

The factor cause slow learner difficulties in learning found in the data accumulated that $12 \%$ of data is related to poverty, $12 \%$ of data is related to parental intelligence, $38 \%$ of 
data is related to emotional factors and $38 \%$ of data is related to personal factors. Emotional and personal factors have greater percentages than the others, it shows that emotional and personal factors affect greatly the causing of the difficulties learning for slow learners. On emotional factors slow learners show unstable while personal problems factors also greatly affect the difficulty of slow learners in learning speaking because this is what distinguishes slow learners from common students. The data analysis from each of points can be seen from the following explanation.

\section{Poverty}

Poverty creates conditions and vulnerabilities that can cause children to learn slowly. For example, poverty can interfere with children's health and learning abilities.

The data show that, almost slow secondary learner's parents at Homeschooling Global Lentera Kasih have their parents' work income exceeding the minimum average wage in Batam. Because data related to wage is considered sensitive, so this data is taken from slow learners' biodata.

Table 1. Parents' Profession

\begin{tabular}{ll}
\hline \multicolumn{1}{c}{ Parent of } & Profession \\
\hline D & Entrepreneur \\
FDF & Employee \\
F & Labor \\
KT & Employee \\
RRH & Trader \\
SRN & Employee \\
NM & Employee \\
PLG & Labor \\
\hline
\end{tabular}

From the documents analyzed it was found that the average slow learner's parents had salaries above the average wage. From the data, it is known that the average slow learners are in the prosperity level. Meanwhile, according to the theory of Reddy, Ramar and Kusuma (2006) it is stated that Poverty creates conditions and vulnerabilities that can cause children to learn slowly, Based on the finding for poverty all the parents member show that poverty not cause slow learner, so the results of the analysis state that this theory is rejected at this point. 


\section{Parental Intelligence in the Family}

Parents who do not have the opportunity to get proper education and a large number of family members can cause their children to learn slowly because parents tend to pay attention to children's intellectual development, do not have time to study with children, and have limitations in providing children's learning facilities, so that children's opportunities to increase speed of learning is almost non-existent.

From the data on the identity of students in homeschooling, it was found that almost all parents of slow learners were educated at elementary and secondary schools although not all of them had degrees. Table 2 show the parents' educational background.

\begin{tabular}{lllc}
\multicolumn{2}{c}{ Table 2. Parent's Education Background } \\
\hline No & Parent of & & Education \\
\hline 1. & D & Father & SMA \\
& & Mother & SMA \\
2. & FDF & Father & D2 \\
& & Mother & SMA \\
3. & F & Father & No School \\
& & Mother & No School \\
4. & KT & Father & D2 \\
& & Mother & SMA \\
5. & RRH & Father & SMA \\
& & Mother & SD \\
6. & SRN & Father & S1 \\
& & Mother & SMA \\
7. & NM & Father & S1 \\
& & Mother & S1 \\
8. & PLG & Father & SD \\
& & Mother & SD \\
\hline
\end{tabular}

Table 2 shows those 7 parents of slow learners at Homeschooling Global Batam, and just one of among their parents uneducated. Its means that parents of slow secondary learners are mostly educated. The percentages of parent's education can be seen from the chart 2 .

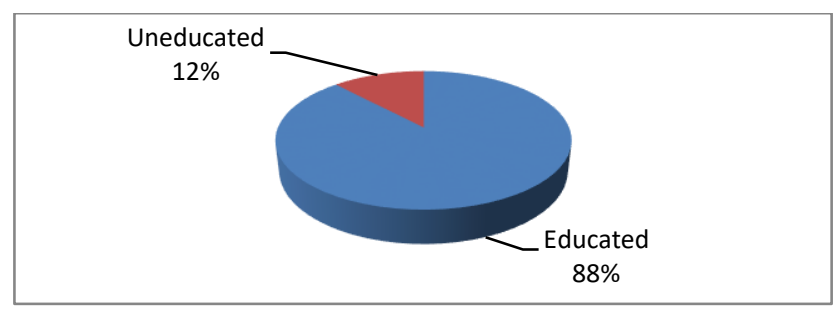

Chart 2 the Proportions of Parents' Education

The chart 2 shows $88 \%$ of parents of slow secondary learners are educated and only $12 \%$ are uneducated, it means that there is only one slow secondary learner's parents who has uneducated from all slow learners in class X at homeschool Global Lentera Kasih Batam, however in chart shows almost of parents are educated, ther are $88 \%$ of them educated, this 
percentages show that seven of slow secondary learners have education. In summarize parental education is not a determining factor that causes slow learner. Meanwhile, based on the theory stated that parents who do not have the opportunity to get proper education and a large number of family members can cause their children to learn slowly, so the theory is not appropriate in this point.

\section{Emotional factor}

The slow learners experience prolonged and emotional problems that hinder the learning process. This emotional problem causes the slow learners to have low learning achievement.

From interview with the parent of SRN, it was found that slow learner tends to be passive in interacting at home with family members. This is supported by the following data:

\section{Data 1/I-10/R/PSRN:}

R: Bagaimana emosi anak di rumah dan interaksinya dengan anggota keluarga lainnya? "How are the slow learners emotions at home and their interactions with other family members?"

P: Ya biasa sih. Ya biasa aja. Yah nggak ini. Karena dia kan modelnya nggak suka banyak ngomong juga jadi yah kalau ada maunya dia. Dia mau ngomong. Kalau nggak perlu kali misalnya kita ajakpun dia ngomong kalau dia tidak tertarik yah ditinggalin. "Yes, usual. Yes, just normal. Well not this, because the model doesn't like to talk too much so yeah if he has what he wants. He wants to talk If you don't need it, then for example, even if we talk to him If he's not interested, leave it."

From data 1, it was shown that SRN is a child who did not talk too much. His parents said that dia kan modelnya nggak suka banyak ngomong juga, so it means SRN is mostly silent and only interacts if there is something he wants. While the theory stated that slow learners experience prolonged and emotional problems that hinder the learning, so if it is related to theory, slow learner emotions tend to be passive. But there were exceptions when he wasn't really interested in something, as the mother of SRN said yah kalau ada maunya dia. Dia mau ngomong. Kalau nggak perlu kali. It means that the response can be more active if there is something that catches his attention

\section{Personal factors}

Personal factors that can cause slow learners include: 1) physical disabilities; 2) the condition of the body affected by disease; 3) have impaired vision, hearing, and speech; 4) absence from school; and 5) lack of self-confidence. The data of personal factors obtained from the results of interviews with the teacher as follows: 


\section{Data 2/I-2/R/PFDF}

R: Menurut ibu adakah personal factor yang membedakan ananda ini dengan anak lainnya? "According to you, are there personals factor that distinguishes slow learner from other children?".

P: Yah nggak inilah nggak banyak bicara dia. Dia lebih banyak tertutup. Iya kayak gitulah dia miss. Dan lainnya agak kesulitan verbalnya dalam berbicara. Dan apa ya.. dulu sebelum terapi dia ini gak percaya diri. Cuma selama sekolah di homeschooling dia jadi lebih percaya diri sekarang miss. "Well she doesn't talk much. She is more introverted. Yes, that's how she miss. And she had a little difficulty verbally in speaking. And what ... before the therapy she was not confident. Only during school in homeschooling she became more confident now miss."

From the interview results above, it can be seen that slow learners have problems with personal factors such as 1) physical disabilities; 2) the condition of the body affected by disease; 3) have impaired vision, hearing, and speech; 4) absence from school; and 5) lack of self-confidence. Likewise what was experienced by FDF, her parents said that FDF agak kesulitan verbalnya dalam berbicara. This emphasizes that personal factors are one of the causes of slow learner difficulty in speaking; especially FDF also has have impaired at speech, so it is certain that this will have an impact on FDF in learning speaking.

\section{CONCLUSIONS AND SUGGESTIONS}

The factors cause slow learner difficulties in learning found the data accumulated that $12 \%$ of data is related to poverty, $12 \%$ of data is related to parental intelligence, $38 \%$ of data is related to emotional factors and $38 \%$ of data is related to personal factors. Then, the dominant factors are emotional and personal factors. From the result of analysis data, it founds that poverty and parent intelligence are not the factors that cause slow learner, while emotional and personal factors are in appropriate with the theory.

To the parents of slow learner for pay more attention, interact more with their children at home, and coordinate with schools in term overcome the difficulties in learning their children. To the teachers are also suggested to register themselves to the teacher organization which will develop and enlarge the skill toward slow learner and It is also suggested to government to give the training to the teacher related how to handling slow learner. To further researcher to find out the other source of data which have more the number of data regarding slow learner or other technique of collecting data. It is better to use other theories in conducting the research related slow learner. 


\section{REFERENCES}

Bogdan, C. Robert and Biklen. 1992. Qualitative Research for Education: An introductionto theory and Method. Boston: Allyin and Bacon.

Bogdan, R. C. 1992. Qualitative Research for Education. California: Pearson A\&B.

Brown, G and Yule, Y. 2001. Teaching the Spoken Language. Cambridge: Cambridge University Press, P13.

Karapetyan Lili, G. 2017. Dealing with Slow Learnes in The Language Class. Vietnamese journal, 6.

Malik, Sangeeta. 2009. Effect of Intervention Training on Mental Abilities of Slow Learners. International Journal Education and Science. 1(1): 61-64

Miles, B., Huberman, Michael A. \& Saldana. 2014. Qualitative Data Analysis: a Methods Sorcebook. Edition 3. USA: SAGE.

Mulyadi, Seto. 2007. Homeschooling Keluarga Kak Seto: Mudah, Murah, eriah, dan Direstui Pemerintah. Bandung: Kaifa PT Mizan Pustaka.

Reddy, G. Lokanadha, R. Ramar, dan A. Kusuma. 2006. Slow Learners: Their Psychology and Instruction. New Delhi: Discovery Publishing House.

Richards, J., and Renandya, W. 2005. Communicative Language Teaching Today. RELCP. Singapore: SEAMEO Regional Language Center.

Vasudevan, A. 2017. Slow learners - Causes, Problems, and Educational Programmes . International Journal of Applied Research 2017; 3(12): 308-313, 6. 